The effects of simultaneous large acidic and alkaline airborne pollutants on forest soil

Haapala, $\mathrm{H}$.

Elsevier Science Ltd.

1997

Haapala, H. et al. 1997. The effects of simultaneous large acidic and alkaline airborne pollutants on forest soil. Environmental Pollution 94(2): 159-168.

http://hdl.handle.net/1975/182

Downloaded from Helda, University of Helsinki institutional repository.

This is an electronic reprint of the original article.

This reprint may differ from the original in pagination and typographic detail.

Please cite the original version. 


\title{
THE EFFECTS OF SIMULTANEOUS LARGE ACIDIC AND ALKALINE AIRBORNE POLLUTANTS ON FOREST SOIL
}

\author{
Heikki Haapala, ${ }^{a}$ Natalia Goltsova, ${ }^{b}$ Victor Pitulko ${ }^{c} \&$ Martin Lodenius ${ }^{a}$ \\ ${ }^{a}$ Department of Limnology and Environmental Protection, PO Box 27, FIN-00014, University of Helsinki, Finland \\ ${ }^{b}$ Biological Institute, Saint Petersburg State University, Russia \& Nansen International Environmental and Remote Sensing Center, \\ Saint Petersburg, Russia \\ 'Saint Petersburg Research Centre for Ecological Safety, Russian Academy of Sciences, Saint Petersburg, Russia
}

(Received 27 December 1995; accepted 28 May 1996)

\begin{abstract}
The effects of air pollutants on soil were studied in Scots pine (Pinus sylvestris L.) forests near the boundary of Russia and Estonia. The study area is characterized by large amounts of acidic and basic pollutants, mainly sulphur dioxide $\left(\mathrm{SO}_{2}\right)$ and calcium $(\mathrm{Ca})$. Several variables were measured in different horizons of the podzolic soil polluted by emissions from local sources in areas of several thousands of square kilometres. Alkalinization dominates the processes in the soil, since sulphur is absorbed only in small quantities and $\mathrm{Ca}$ is much better absorbed. Ca content in humus horizon may rise even to $100000 \mathrm{mg} \mathrm{kg} \mathrm{g}^{-1}$ and the $\mathrm{pH}$ of originally very acidic soil may rise to 8.3. Total aluminum ( $\mathrm{Al}$ ) content was high in the heavily polluted plots, since emissions contain much Al. On the other hand, the exchangeable Al was very low in these alkaline sites. A larger quantity of exchangeable Al occurred farther from the pollutant sources, even though total Al in these plots was low. These plots had acidic soils in which Al is in exchangeable form. Due to the neutralizing effect of acidic and basic pollutants, forest damage in the study area was not as serious as might be supposed. Complicated pollutant situations must be taken into consideration when pollution-caused environmental protection measures are planned. It is not reasonable to reduce only $\mathrm{SO}_{2}$ emissions, but necessary to lower the basic emissions at the same time. (C) 1997 Elsevier Science Ltd. All rights reserved.
\end{abstract}

Keywords: Soil pollution, pine forests, sulphur-emissions, alkaline pollutants, calcium, aluminium.

\section{INTRODUCTION}

Large industrial complexes are situated on both sides of the northern boundary between Russia and Estonia, an area heavily polluted by energy production and industry (Haapala et al., 1996a). The largest emissions originate from the energy power plants of Narva in northeastern Estonia, which use shale oil containing $50 \%$ inorganic material. These plants are known for their sulphur dioxide $\left(\mathrm{SO}_{2}\right)$ emissions: $141000 \mathrm{t}$ in 1992 and $97000 \mathrm{t}$ in 1993 (VTT, 1994), the decline resulting from decreasing energy production.

Less attention has been paid to the dust emissions of these power plants, although these emissions are more massive, being $186000 \mathrm{t}$ in 1992 and $135500 \mathrm{t}$ in 1993 (VTT, 1994). Other large sources of particle emissions in the same region are the cement industry of Kunda in northeastern Estonia (82600 t in 1990; Kallaste et al., $1992)$ and the Slantsy cement and oil-shale industry on the Russian side (62800 t in 1990; Haapala et al., 1993). The particle emissions of Narva, Kunda, and Slantsy are together 5-6 times larger than the Finnish particle emissions from industry and energy production combined. In addition, several other large particle-emission sources are situated in the study area, including largescale mining industry.

Particle emissions in this area are often alkaline, due to their basic cations, mainly calcium (Ca). The $\mathrm{pH}$ of fly ash in Kunda is about 12.5. In northeastern Estonia, $\mathrm{pH}$ values in excess of 9 have been measured in snow (Kallaste et al., 1992). Alkaline emissions neutralize the acidic effect of sulphurous emissions. Since both alkaline and acidic emissions are simultaneously very high, a peculiar situation prevails in the study area, the effects of which are not yet known.

Studies of air pollutants in the study area have been summarized by Goltsova (1994). Separate studies have been published by Mäkinen (1994), concerning the Estonian side, and by Haapala et al. (1993, 1996a) and Seppälä et al. (1993), concerning the Russian side. Until now, however, no systematic study of the environmental damage has been published. A good understanding of the situation can be obtained from the map published by Goltsova (1994), in which the number of epiphytic lichen species on pine trunks are shown. According to this map, lichens are missing over a $1000-\mathrm{km}^{2}$ area, and less severe damage occurs over a much larger region. Forest damage is seen in many places, with the injured areas being scattered. The study area is characterized by wide and almost virgin forests, which act as pollutant sinks, suffering from the effects of pollutants and at the same time eliminating these effects. 
The special character of alkaline air pollutants on the study area is indicated by exceptional pine epiphytes, namely the lichen Xanthoria parietina (L.)Th.Fr. and the green alga Trentepohlia umbrina (Chlorophyceae, Chaetophorales), which makes pine trunks appear red (Haapala et al., 1993, 1996a). The effect of acidic and alkaline pollutants is also shown by high concentrations of S and Ca in pine needles (Haapala et al., 1993, 1996a). The effects of air-borne heavy metals are considerable but not severe (Goltsova \& Vasina, 1993; Mäkinen, 1994).

The effects of air pollutants on the forest soil are not known. In this work, these effects were studied in the western part of the Leningrad region, which is affected also by the Narva power plants and other northeastern Estonian sources. Major attention was paid to acidbase problems in the soils. Heavy-metal concentrations were measured, but these findings are reported in a separate article (Haapala et al., 1996b).

\section{MATERIAL AND METHODS}

\section{Study area}

The study area is situated in the western part of the Leningrad administrative region. The main sources of air pollutants can be seen in Fig. 1. The Narva power plants are situated just west of the study area. The main wind direction is to the northeast toward the study area (Fig. 1, insert).

Studies were performed on 41 sample plots situated in forests of Scots pine, Pinus sylvestris (L.), mainly on sandy soils. For total element analyses, 80 sample plots were used. Similar Scots pine forest sites were selected for the study; however, not in every case was this selection possible due to different geological conditions and to the long-term air pollution effect on vegetation and soil. The soil parent material was formed in the last ice age. In all plots, a podzol profile was present. In the north, the underlying ancient rocks are silicates, whereas, in the south, carbonate rocks predominate. The soils in the north are more podzolized, more acidic, and hence contain fewer alkaline cations.

The sample plots were divided into six groups.

(1) First Slantsy area, distance from Slantsy plants $1-6 \mathrm{~km}$ (five sample plots).

(2) Second Slantsy area, distance $7-20^{*} \mathrm{~km}$ (six sample plots).

(3) Third Slantsy area, distance 15-35* km (seven sample plots).

(4) First Narva area, distance from Narva power plants $8-20 \mathrm{~km}$ (seven sample plots).

(5) Second Narva area, distance $20-40 \mathrm{~km}$ (eight sample plots)

(6) 'Background' areas (relatively unpolluted), distance from main pollutant sources $40-50 \mathrm{~km}$ (eight sample plots).

*The second Slantsy area was longer in the main wind direction (northeast, $20 \mathrm{~km}$ ) than to other directions $(15 \mathrm{~km})$.
On each plot, samples from the humus, eluvial, and illuvial horizons were taken. Two samples on each plot, both of them containing five subsamples, were taken with a cylinder and combined into a single sample for each plot and horizon. The samples were air-dried to constant weight. Particle size, water content and organic matter content were determined, and $\mathrm{pH}$ was measured in water (soil to water $1: 2 \mathrm{v} / \mathrm{v}$ ) and in $1 \mathrm{M} \mathrm{KCl}(1: 10 \mathrm{v} / \mathrm{v}$ ) suspensions; $\mathrm{pH}$ was also measured for pine bark samples. Elemental concentrations of $\mathrm{Al}, \mathrm{Ba}, \mathrm{Ca}, \mathrm{Cd}$, $\mathrm{Cr}, \mathrm{Cu}, \mathrm{Fe}, \mathrm{K}, \mathrm{Mg}, \mathrm{Mn}, \mathrm{Na}, \mathrm{Ni}, \mathrm{Pb}, \mathrm{S}, \mathrm{V}$ and $\mathrm{Zn}$ were determined from $\mathrm{HNO}_{3}$ (total content) and from $1 \mathrm{M}$ ammonium acetate (exchangeable content; $1: 10 \mathrm{v} / \mathrm{v}, \mathrm{pH}$ 4.65) extractions. Exchangeable $\mathrm{Al}$ was measured in $\mathrm{KCl}$ extracts. For $\mathrm{HNO}_{3}$ extraction, $1 \mathrm{~g}$ of soil was digested in $20 \mathrm{ml}$ of $\mathrm{HNO}_{3}$ (acid to water 1:1 v/v) for $20 \mathrm{~h}$ in $20^{\circ} \mathrm{C}$, then $1-2 \mathrm{ml}$ of $\mathrm{H}_{2} \mathrm{O}_{2}$ was added and boiled for $2 \mathrm{~h}$ in $240^{\circ} \mathrm{C}$.

Analysis were performed in St. Petersburg in the MECHANOBR ANALIT laboratory, which participates

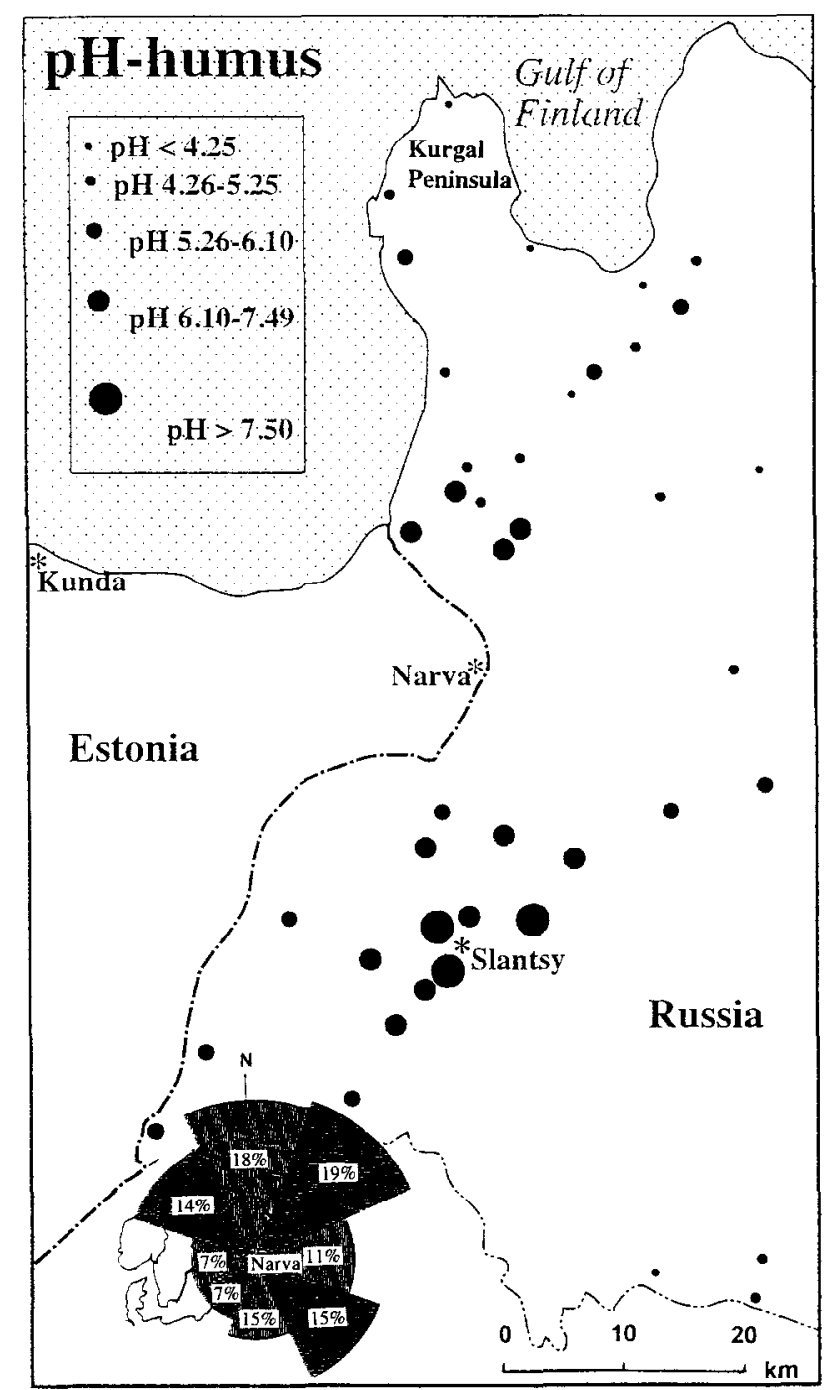

Fig. 1. $\mathrm{pH}$ in the humus horizon of the Scots pine forests of the study area. Insert: proportional distribution of $\mathrm{SO}_{2}$ emissions of Narva energy plants in various wind directions (according to Mäkinen, 1994). 
in international intercalibration. An inductively coupled plasma emission spectrophotometer (ICP, PST, BAIRD) and an atomic absorption spectrophotometer (PERKIN ELMER, Model No 5100 PC) were used for the measurements. Exchangeable acidity was determined for the $0.1 \mathrm{M} \mathrm{BaCl}_{2}$ extractions $(1: 10 \mathrm{v} / \mathrm{v})$ by titration with $\mathrm{NaOH}$ to an endpoint of $\mathrm{pH} 7.00$.

For statistical calculations (one-way analysis of variance, Pearson correlations, descriptive statistics), Statistix Version 4.1. was used.

\section{RESULTS AND DISCUSSION}

\section{Acidity and alkalinity of the soil}

The original acidic podzolic soil has become neutral or even alkaline over wide areas (Fig. 1) as a result of areal pollutants. These contaminants have accumulated over the last 30 years after the beginning of the intense industrialization of this region. This finding was somewhat unexpected, since the area was known for the acidic sulphurous pollutants originating from the Narva energy plants. Some earlier soil $\mathrm{pH}$ measurements in Estonia did not reveal such a strong alkaline effect (Mäkinen, 1994). The alkaline effect is not only restricted to the surface soil. In the vicinity of Slantsy's pollutant sources, even our deepest samples $(30 \mathrm{~cm})$ showed a $\mathrm{pH}_{\mathrm{H}_{2} \mathrm{O}}$ value of 8.3. Soils in equilibrium with $\mathrm{CaCO}_{3}$ have a pH of 8.3 (Thomas \& Hargrove, 1984). Compared to the forest liming, this alkaline effect reaches to deeper horizons, since the effect of forest liming is found only in the humus horizon, which has a great capacity for base neutralizing (Kreutzer, 1995).

In the study area, most alkaline sample plots are located in close proximity to the Slantsy cement and oilshale works (Figs 1 and 2). Sample plots 10-20 km from Slantsy were less acidic than those situated at an equal distance from the Narva power plants. The difference was statistically significant (one-way analysis of variance,
LSD(T) pairwise comparison of means, rejection level $0.05)$. The same was true when the sample plots at a distance of $20-40 \mathrm{~km}$ from these two pollutant sources were compared.

On peripheral sample plots, the alkaline effect was lacking. For instance, in the northern part of the Kurgal Peninsula about 45-50 km north of Narva, an unchanged silicate podzol profile was identified with a humus $\mathrm{pH}$ clearly lower than 4 and the $\mathrm{pH}$ of underlying soil horizons about 5. These spatial differences were also observed in the eluvial horizon (Fig. 2). In many sample plots, $\mathrm{pH}$ values exceeded 7 . On the other hand, the eluvial horizon in the periphery zone was generally acidic. The illuvial horizon was also alkaline in some plots. The highest $\mathrm{pH}$ value ( 8.3 ) was measured in the eluvial horizon of some of the profiles of soils near the Slantsy cement and oil-shale works.

In places where airborne pollutants had the greatest alkaline effect on soil $\mathrm{pH}$, the illuvial horizon was generally less alkaline than the upper horizons, with the exception of area 2 (Slantsy 7-20 km), where the alkaline effect was relatively stronger in deeper horizons (Fig. 2). In places where the alkaline effect was very small, the humus horizon was mostly acidic horizon ('background').

In comparison to other cases of alkaline air pollution, the effects in the study area were truly on a massive scale. In the Niepolomice forest (Poland, $25 \mathrm{~km}$ northeast of Kraków), effects of different industrial dusts on the soil were studied experimentally. In the most alkaline case, plots were treated with dust from a cement plant totalling $75 \mathrm{t}$ ha ${ }^{1}$ over 1.5 years. The dust contained $47 \% \mathrm{CaO}$ at $\mathrm{pH} 9.5$. After 5 years, the maximum $\mathrm{pH}$ for the topsoil was 7.7. Below the uppermost $5-\mathrm{cm}$ soil layer, the maximum was pH 6.1 (Greszta, 1988a,b). In Kalkkiranta (Finland, $25 \mathrm{~km}$ east of Helsinki), the long-lasting effect of a limestone quarry changed the $\mathrm{pH}$ of a podzolic humus soil of the surrounding forest from about 4 to over 7 (Huttunen et al., 1990). Even in this case, however, the alkaline effect is smaller than that of

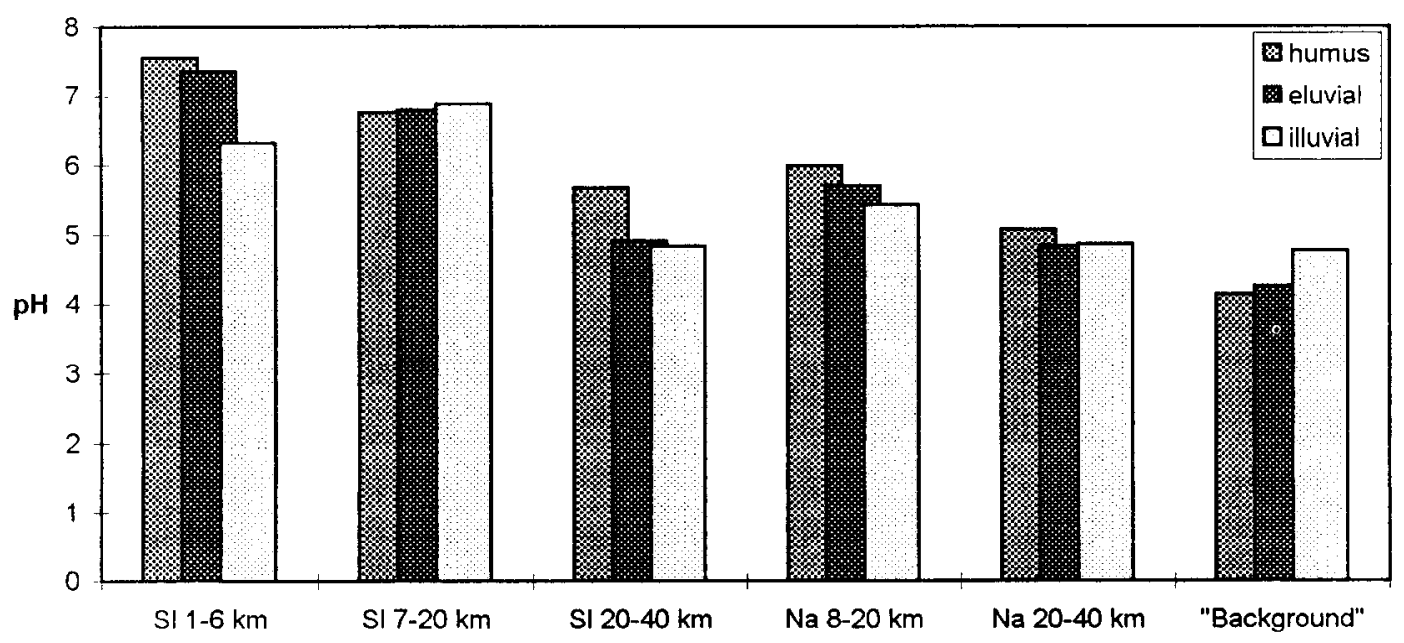

Fig. 2. $\mathrm{pH}$ in different horizons of the Scots pine forests in different parts of the study area. Sl 1-6 km, Sl 7-20 km, and Sl 15$35 \mathrm{~km}$ mean distance from Slantsy, $\mathrm{Na} 8-20 \mathrm{~km}$ and $\mathrm{Na} 20-40 \mathrm{~km}$ mean distance from Narva (see Material and Methods section). 
Slantsy. Only minor changes in soil $\mathrm{pH}$ have been caused by liming experiments in Finnish coniferous forests, in which limestone additions were $2 \mathrm{t} \mathrm{ha}^{-1}$. Humus $\mathrm{pH} 20$ years after that liming was only one $\mathrm{pH}$ unit higher than before the liming, the effect being even less in mineral soil, although almost all limestone Ca still remained in the soil (Derome \& Pätilä, 1990).

\section{Soil calcium}

The alkaline effect observed in the soil was mainly caused by Ca-containing compounds, the content of which is high in both the Narva and Slantsy emissions. The highest total $\mathrm{Ca}$ content of humus was $100000 \mathrm{mg} \mathrm{kg}^{-1}$ (in the vicinity of Slantsy, Fig. 3). On the Estonian side of the boundary, high $\mathrm{Ca}$ concentrations in soil have also been measured (Mäkinen, 1994), although not so high as in the present study. In the Polish Niepolomice forest the highest total $\mathrm{Ca}$ content was $21500 \mathrm{mg} \mathrm{kg}^{-1}$ (Greszta, 1988a,b).

The concentrations of exchangeable $\mathrm{Ca}$ were correspondingly very high. Exchangeable $\mathrm{Ca}$, like other basic cations, is accumulated by air pollution in the humus horizon (Table 1). Near Slantsy the highest concentrations were over $20000 \mathrm{mg} \mathrm{kg}^{-1}$ in the humus horizon (Fig. 4), $7000 \mathrm{mg} \mathrm{kg}^{-1}$ in the eluvial horizon and over $1000 \mathrm{mg} \mathrm{kg}^{-1}$ at the depth of $30 \mathrm{~cm}$ in the illuvial horizon. The highest values were almost twofold greater than those reported for the Finnish Kalkkiranta forest near the limestone quarry (Huttunen $e t$ al., 1990). Differences in Ca content between different parts of the study area were great (Figs 3 and 4). Total Ca contents were about tenfold greater near Slantsy than in the peripheric zone. In fact, soil $\mathrm{Ca}$ values were increased across the entire study area. Even $60 \mathrm{~km}$ northeast from the pollutant sources, soil Ca content was about twofold the background values, which were approximately $4000 \pm 1000 \mathrm{mg} \mathrm{kg}^{-1}$ (Tamminen \& Starr, 1990). On the other hand, some comparatively low $\mathrm{Ca}$ concentrations were also measured.

Ca pollution has greater effects on soil near Slantsy than in the surroundings of Narva. The differences are similar in total and extractable contents. These differences were also detected in deeper soil horizons. At the $30 \mathrm{~cm}$ depth, area numbers 1 and 2 around Slantsy differed significantly from all other areas in their $\mathrm{Ca}$ contents, the greatest concentrations being also in this case about tenfold greater than in the least polluted areas.

High Ca content may have an important impact on forest soil and the whole ecosystem (Kreutzer, 1995). Positive effects are de-acidification of soil, reduction in mobility of toxic species of $\mathrm{Al}$ and heavy metals and

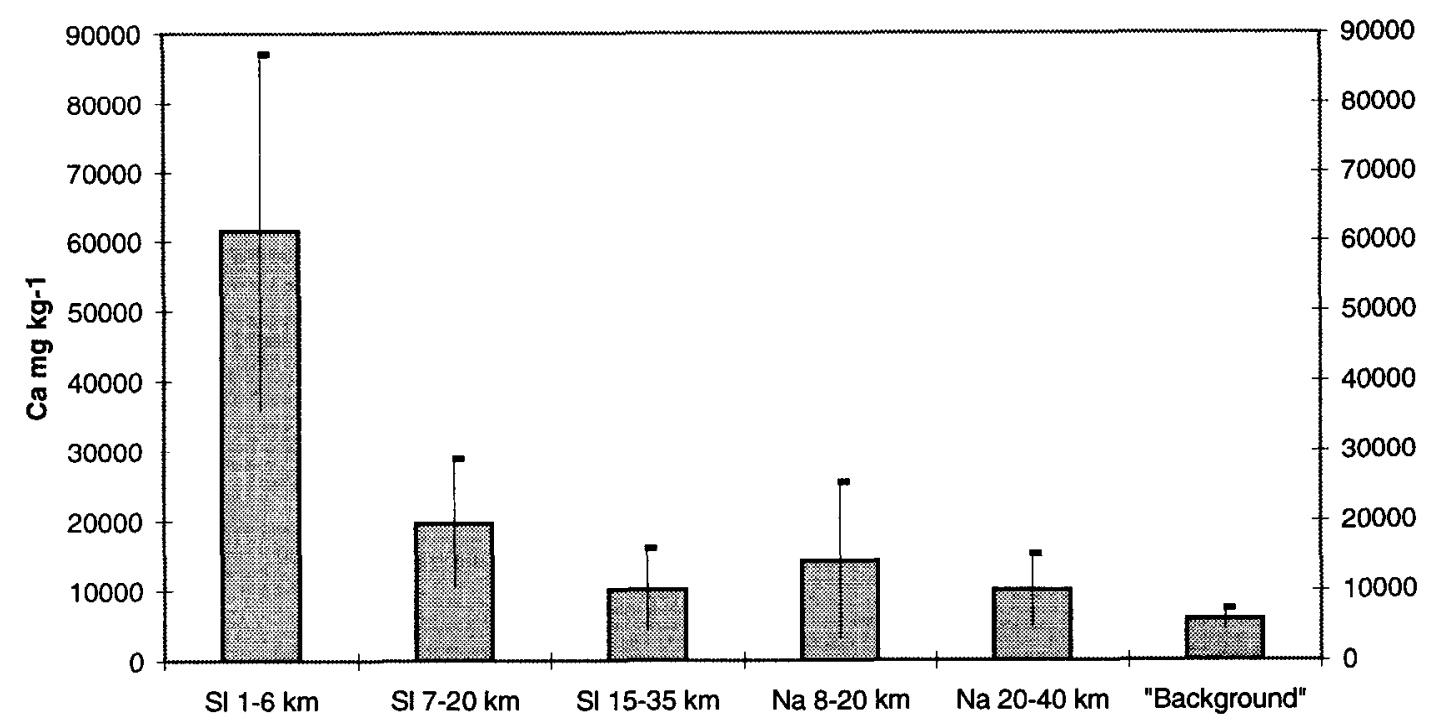

Fig. 3. Total calcium content in the humus horizon of the Scots pine forests in different parts of the study area. The bars of the columns indicate standard deviation. For further explanations, sce Fig. 2.

Table 1. Total and exchangeable (different horizons) element content $\left(\mathrm{mg} \mathrm{kg}^{-1}\right)$ of the Scots pine forest soil of the study area

\begin{tabular}{|c|c|c|c|c|c|c|c|}
\hline & Al & $\mathbf{S}$ & $\mathrm{Ca}$ & $\mathrm{Ba}$ & $\mathbf{K}$ & $\mathbf{M g}$ & $\mathrm{Na}$ \\
\hline Total $n$ & 80 & 78 & 80 & 80 & 80 & 79 & 79 \\
\hline Humus mean & 4857 & 1201 & 11730 & 74 & 1599 & 837 & 82 \\
\hline SD & 3636 & 726 & 14100 & 36 & 1868 & 831 & 56 \\
\hline Exchangeable $n$ & 41 & 41 & 41 & 41 & 41 & 41 & 41 \\
\hline Humus mean & 54 & 313 & 7137 & 18 & 390 & 346 & 25 \\
\hline SD & 75 & 578 & 5893 & 12 & 211 & 292 & 22 \\
\hline Eluvial mean & 45 & 25 & 967 & 6 & 47 & 54 & 5 \\
\hline SD & 13 & 28 & 1733 & 10 & 41 & 88 & 6 \\
\hline Illuvial mean & 83 & 18 & 190 & 3 & 18 & 14 & 6 \\
\hline $\mathrm{SD}$ & 264 & 17 & 268 & 4 & 16 & 26 & 7 \\
\hline
\end{tabular}


improvement in humus quality resulting from better conditions for soil organisms (Metzner \& Meuwes, 1991; Derome et al., 1994; Kreutzer, 1995). An increase in soil Ca content may also have negative effects, such as an increase in nitrate concentration of seepage water, reduction in the humus store, mobilization of copper and lead as organic complexes, induction of boron deficiency and damage to roots and their mycorrhizae (Lehto, 1984, 1994; Kreutzer, 1995). Many of these effects have been observed in liming experiments, and the effects of $\mathrm{Ca}$ are in many cases indirect. In the study area, the increase in soil Ca content was totally uncontrolled, and in many places much greater than in normal liming.

\section{Other basic cations}

Total concentrations of magnesium $(\mathrm{Mg})$, potassium $(\mathrm{K})$, sodium $(\mathrm{Na})$, and barium $(\mathrm{Ba})$ have clearly increased in the same sample plots as $\mathrm{Ca}$, and they correspond to Ca fluctuations. All are considered to originate from the same pollutant sources. The amounts of $\mathrm{Mg}$ and $\mathrm{K}$ are so high that they have a considerable effect on soil alkalinity. However, the Ca content was clearly most dominant. The exchangeable-element content of $\mathrm{Mg}, \mathrm{K}$, and $\mathrm{Ba}$ correlated well with that of calcium, but Na did not (Table 2).

The amount of alkaline cations was very high compared to that of similar soil types in Finland (Tamminen \& Starr, 1990) and, especially in the case of $K$, was much higher than soil $\mathrm{K}$ content in ash experiments in Niepolomice, Poland (Greszta, 1988a,b). On the mostpolluted plots, even more than $90 \%$ of the $\mathrm{K}$ was in non-exchangeable form.

\section{Soil aluminum}

The amount of Al differs from that of alkaline cations. Total Al content was very high in the plots that showed high concentrations of alkaline cations (Fig. 5). The correlation of total Al with total alkaline cations was strongly positive (Table 2), as a result of air pollution, which contains a lot of Al from Narva and Slantsy. On the other hand, concentrations of exchangeable $\mathrm{Al}$ (mainly $\mathrm{Al}^{3+}$ ) differed substantially in distribution, being very low in sample plots where total $\mathrm{Al}$ and $\mathrm{Ca}$

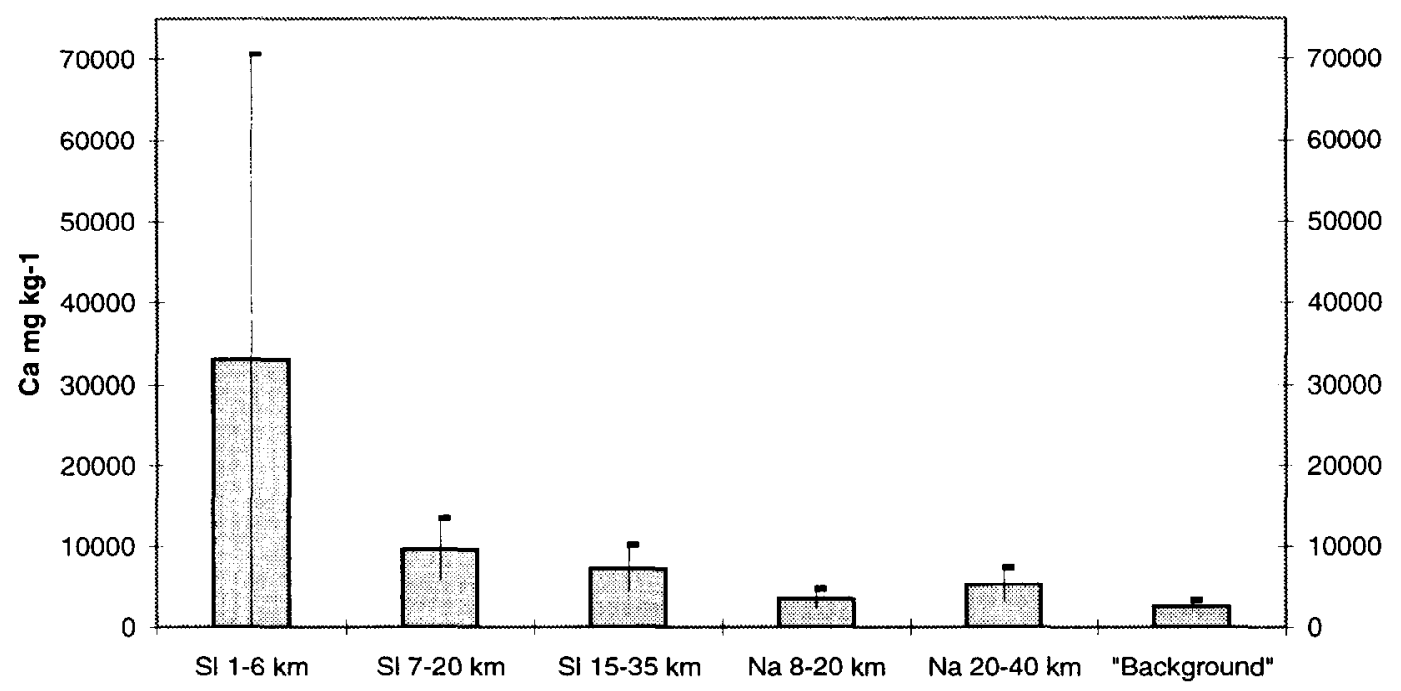

Fig. 4. Exchangeable calcium content in humus horizon of the Scots pine forests in different parts of the study area. For further explanations, see Figs 2 and 3.

Table 2. Correlations (Pearson) for total (tot, $\mathrm{df}=77$ ) and exchangeable (exc, $\mathrm{df}=39$ ) element content in the humus horizon of the Scots pine forests of the study area

\begin{tabular}{|c|c|c|c|c|c|c|}
\hline & $\mathrm{Al}$ & $\mathrm{S}$ & $\mathrm{Ca}$ & $\mathrm{Ba}$ & $\mathrm{K}$ & $\mathrm{Mg}$ \\
\hline$S$ tot & 0.192 & & & & & \\
\hline$S$ exc & -0.026 & & & & & \\
\hline $\mathrm{Ca}$ tot & $0.894^{* *}$ & 0.137 & & & & \\
\hline Ca exc & $-0.386^{*}$ & 0.013 & & & & \\
\hline $\mathrm{Ba}$ tot & $0.775^{* *}$ & $0.359^{* *}$ & $0.689^{* *}$ & & & \\
\hline Ba exc & -0.218 & 0.022 & $0.595^{* *}$ & & & \\
\hline $\mathrm{K}$ tot & $0.927^{* *}$ & 0.135 & $0.952 * *$ & $0.688^{* *}$ & & \\
\hline $\mathrm{K}$ exc & -0.096 & 0.025 & $0.504 * *$ & $0.548 * *$ & & \\
\hline $\mathrm{Mg}$ tot & $0.886^{* *}$ & 0.196 & $0.959 * *$ & $0.696^{* *}$ & $0.961 * *$ & \\
\hline Mg exc & $-0.333^{*}$ & 0.008 & $0.932 * *$ & $0.584 * *$ & $0.639 * *$ & \\
\hline Na tot & $0.746^{* *}$ & $0.321 * *$ & $0.801^{* *}$ & $0.655^{* *}$ & $0.857 * *$ & $0.867^{* *}$ \\
\hline $\mathrm{Na}$ exc & 0.063 & $0.628^{* *}$ & 0.028 & 0.004 & 0.303 & 0.151 \\
\hline
\end{tabular}

${ }^{*} \alpha \leq 0.05,{ }^{* *} \alpha \leq 0.01$. 
content was high (Fig. 6). Exchangeable Al was high in plots with low $\mathrm{Ca}$ content and low $\mathrm{pH}$, even though their total $\mathrm{Al}$ content was very small. The correlation of exchangeable $\mathrm{Al}$ with exchangeable $\mathrm{Ca}$ was negative (Table 2). When total and exchangeable Al contents were compared, differences between sample plots were quite striking. The ratio of total $\mathrm{Al}$ to exchangeable $\mathrm{Al}$ in polluted arcas was greater than 1000 and in lcss polluted samples was about 10 . Unlike basic cations, $\mathrm{Al}$ is not accumulated in the humus horizon (Table 1).

These differences are caused by soil acidity-alkalinity interactions. Because acidification mobilizes Al, much exchangeable $\mathrm{Al}$ can be found in acidic soil, despite the total $\mathrm{Al}$ content not being very high. In alkaline soil, $\mathrm{Al}$ is in insoluble form, and only very little occurs in an exchangeable form. Another reason for this low Al content is the cation-exchange reaction in which $\mathrm{Ca}$ exchanges ionized Al from soil into soil water (Alva \& Sumner, 1990).
Similarly, the ratio of exchangeable Ca to exchangeable $\mathrm{Al}$ changed enormously in different parts of the study area. Near Slantsy the ratio of $\mathrm{Ca}^{2+}$ to $\mathrm{Al}^{3+}$ was higher than 10000 , whereas in less polluted acid mineral soils it was under 0.1 (Fig. 7).

\section{Exchangeable acidity}

Exchangcablc acidity (EA) showed an almost similar areal distribution as that of $\mathrm{Al}$ (Fig. 8). EA values were low in areas with much $\mathrm{Ca}$, high $\mathrm{pH}$ and little exchangeable aluminum and were high for the opposite relationship. In heavily polluted sites, $\mathrm{Ca}$ and other cations have forced out those hydrogen ions that were bound to the negatively charged soil particles. EA had its highest positive correlation with exchangeable $\mathrm{Al}$ (in humus $r=0.933, \mathrm{df}=38$ ) and a negative correlation with $\mathrm{pH}$ (in humus -0.729 ) and exchangeable $\mathrm{Ca}$ (in humus $-0.376)$.

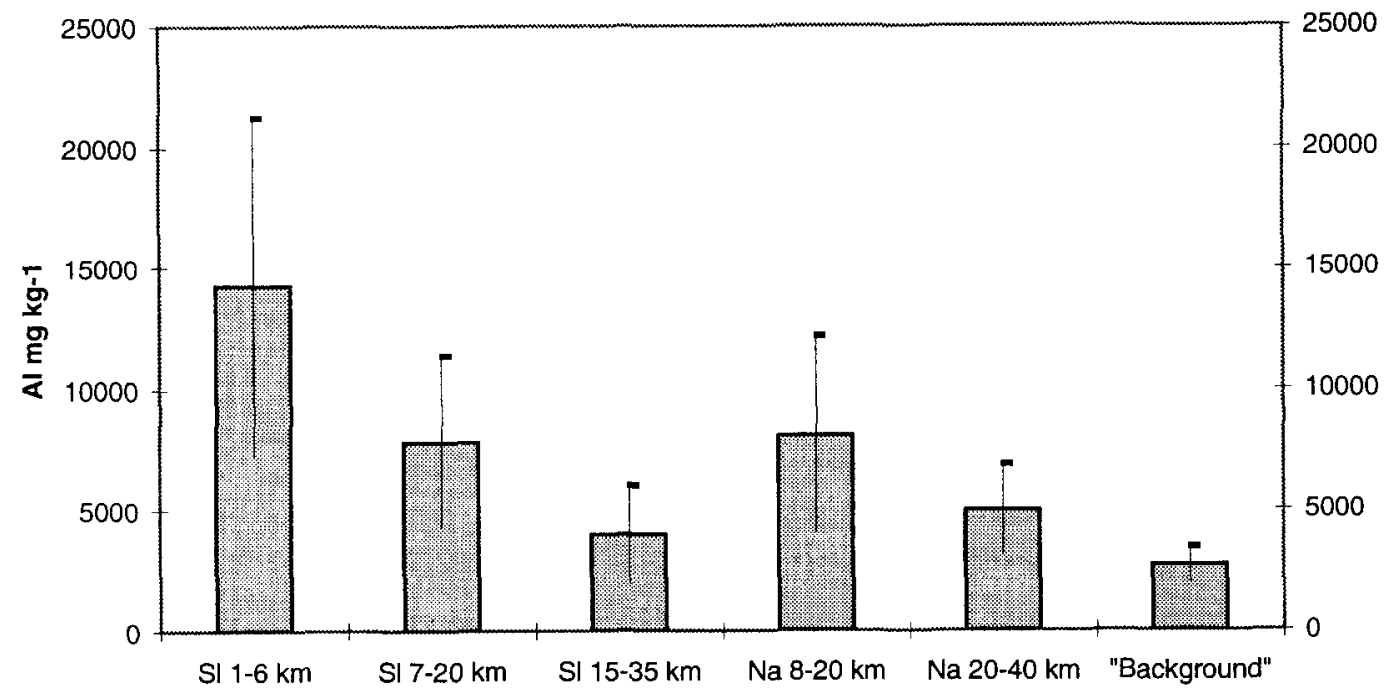

Fig. 5. Total aluminum content in humus horizon of the Scots pine forests in different parts of the study area. For further explanations, see Figs 2 and 3.

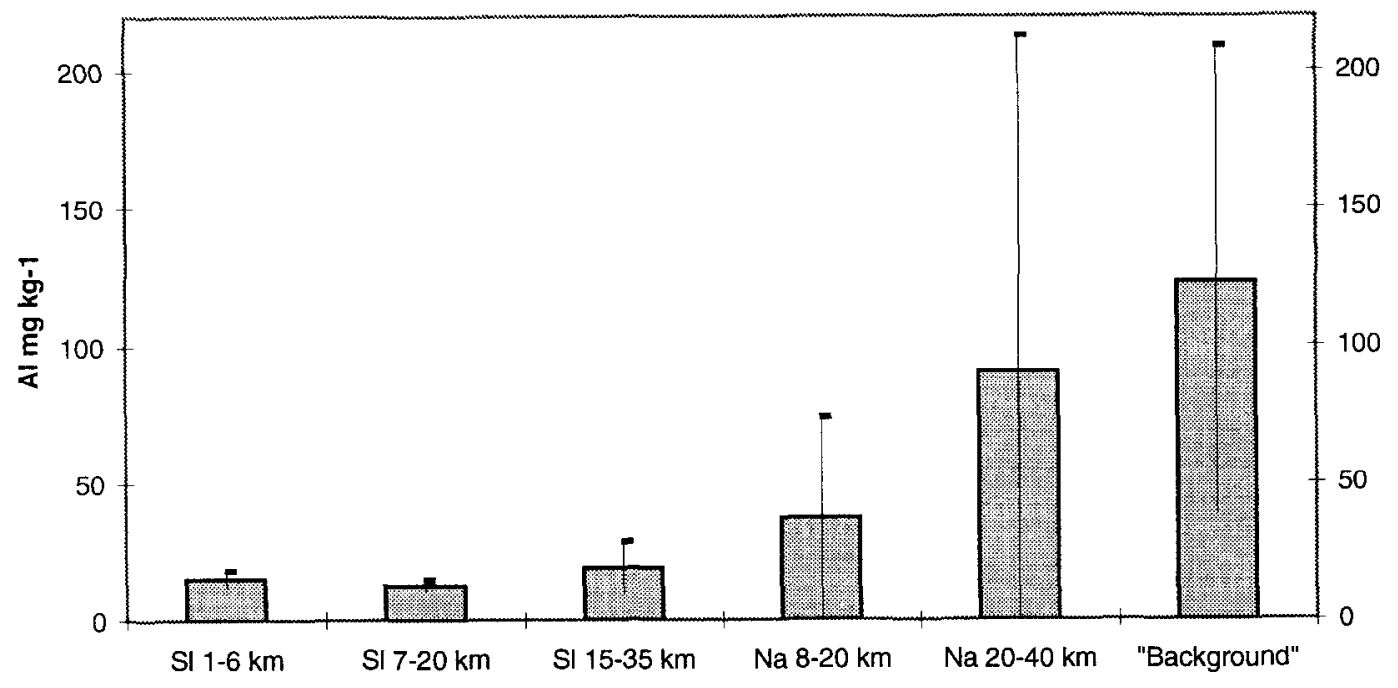

Fig. 6. Exchangeable aluminum content in humus horizon of the Scots pine forests in different parts of the study area. For further explanations, see Figs 2 and 3. 


\section{Sulphur in soil}

The highest total $\mathbf{S}$ content in humus horizon was $4200 \mathrm{mg} \mathrm{kg}^{-1}$, and in four cases its value was higher than $3000 \mathrm{mg} \mathrm{kg}^{-1}$ (Fig. 9). In different parts of the study area, changes in $\mathrm{S}$ content differed from those of most other elements, especially Ca (Figs 9 and 10). The highest soil $S$ contents were in areas 4 and 5 (to the north and northeast of Narva). This finding indicates the very high $\mathrm{S}$ emissions of the Narva energy plants, about tenfold those of Slantsy (Synthesis Report, 1991), even though the differences are not statistically significant due to the very great variations inside the areas. However, it must be remembered that the effects of air pollutants from Narva and Slantsy cannot be separated totally, since the distance between them is only about $25 \mathrm{~km}$.

Soil $\mathrm{S}$ content in the study area was not very great, considering the large $S$ emissions from the local pollutant sources and especially when it is compared to the very high $\mathrm{Ca}$ content of the soil. Similar observations have been made in another area heavily polluted by $S$, namely Montsegorsk in the Kola Peninsula, where soil $\mathrm{S}$ content is almost similar to that in the present area
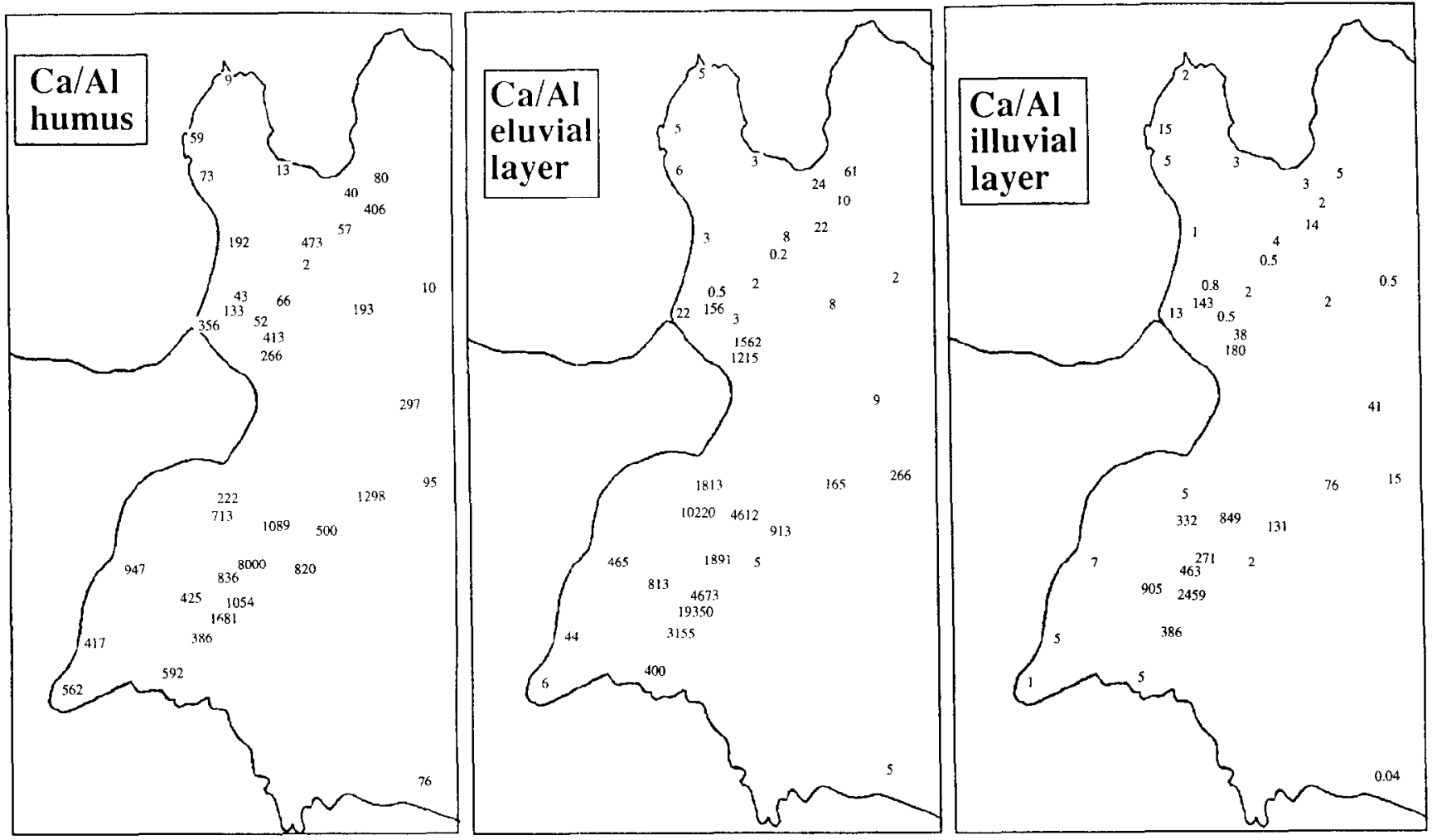

Fig. 7. Ratio of exchangeable $\mathrm{Ca} / \mathrm{Al}$ in various horizons of the podzolic soil of the Scots pine forests of the study area.

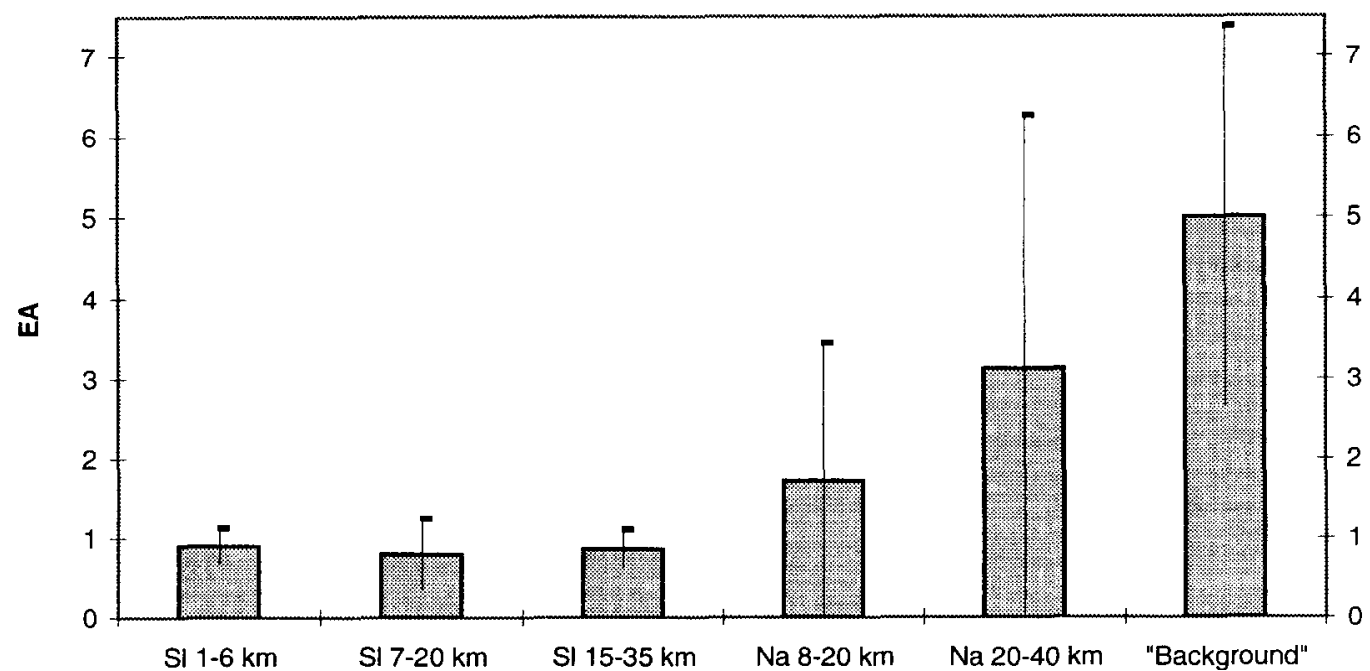

Fig. 8. Exchangeable acidity in humus horizon of the Scots pine forests in different parts of the study area. For further explanations, see Figs 2 and 3. 
(Menshikova et al., 1993). The S level of the soil was of the same order of magnitude as that of Norrliden, Sweden (Nömmik et al., 1984) or around Oulu in northern Finland (Ohtonen et al., 1989).

This relatively low level of $S$ in the soil is not easy to explain, since the chemical reactions of $\mathbf{S}$ in soil are very complicated. Especially under these exceptional conditions, very great differences in soil $\mathbf{S}$ content were found even between sample plots situated near each other.

Only a small portion of the $\mathrm{S}$ is absorbed in the surface horizons of podzolic soil (Neary et al., 1987). This probably results from the fact that sulphate ions and other negatively charged $\mathbf{S}$ ions cannot replace the negatively charged hydroxyl ions in the surface of soil humus and inorganic colloid particles. The absorption of sulphate is also strongly dependent on soil pH, the optimum being under $\mathrm{pH} 4$. In less acidic soils, sulphate absorption is greatly weakened (Nömmik et al., 1984). These experimental studies support the finding that only relatively small amounts of $S$ will be found in podzolic soils simultaneously polluted by $S$ and $\mathrm{Ca}$, the total effect being alkalinization of the soil.

\section{CONCLUSIONS}

The soil of the pine forests in the study area has been polluted by emissions from local sources over areas comprising several thousands square kilometres. The area is characterized by both acidic and alkaline pollutants, mainly $\mathrm{S}$ and $\mathrm{Ca}$. They neutralize each other's effects. However, the absorption of these elements occurs differently. $\mathbf{S}$ (mainly deposited as sulphate) is absorbed only in small quantities, making the $\mathrm{S}$ content

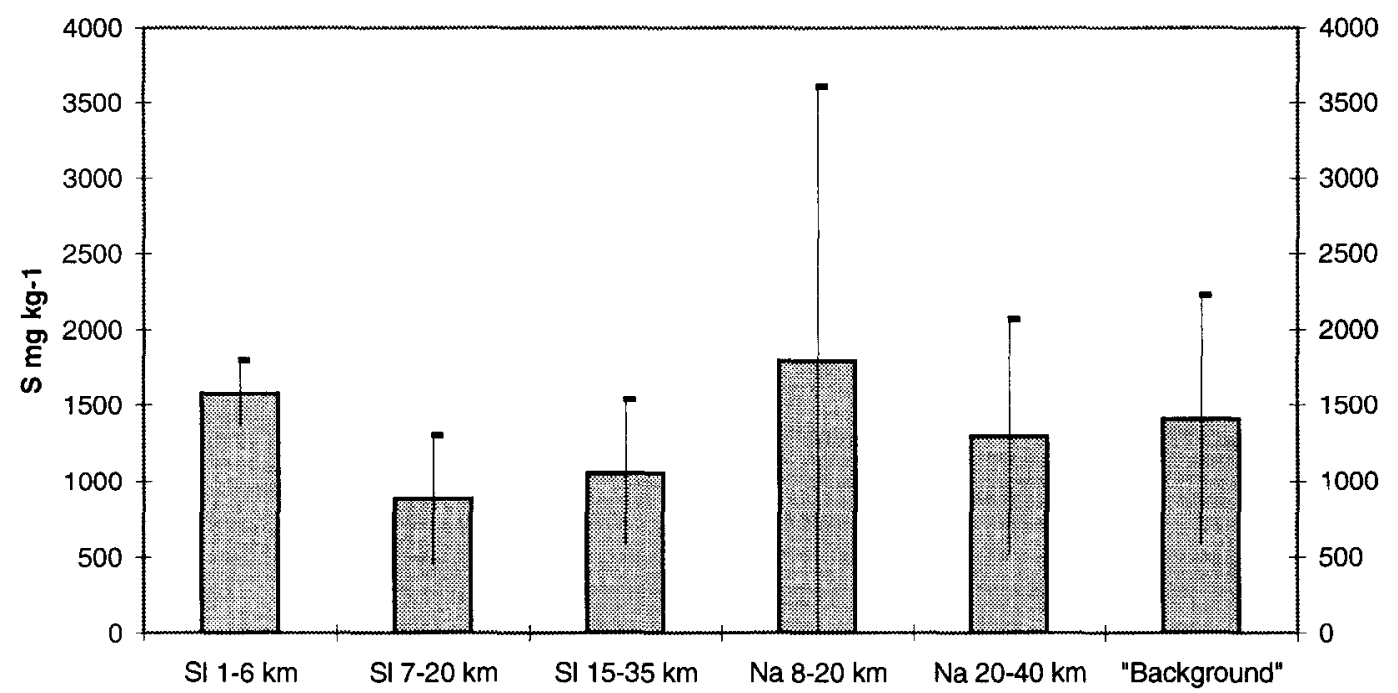

Fig. 9. Total sulphur content in humus horizon of the Scots pine forests in different parts of the study area. For further explanations, see Figs 2 and 3.

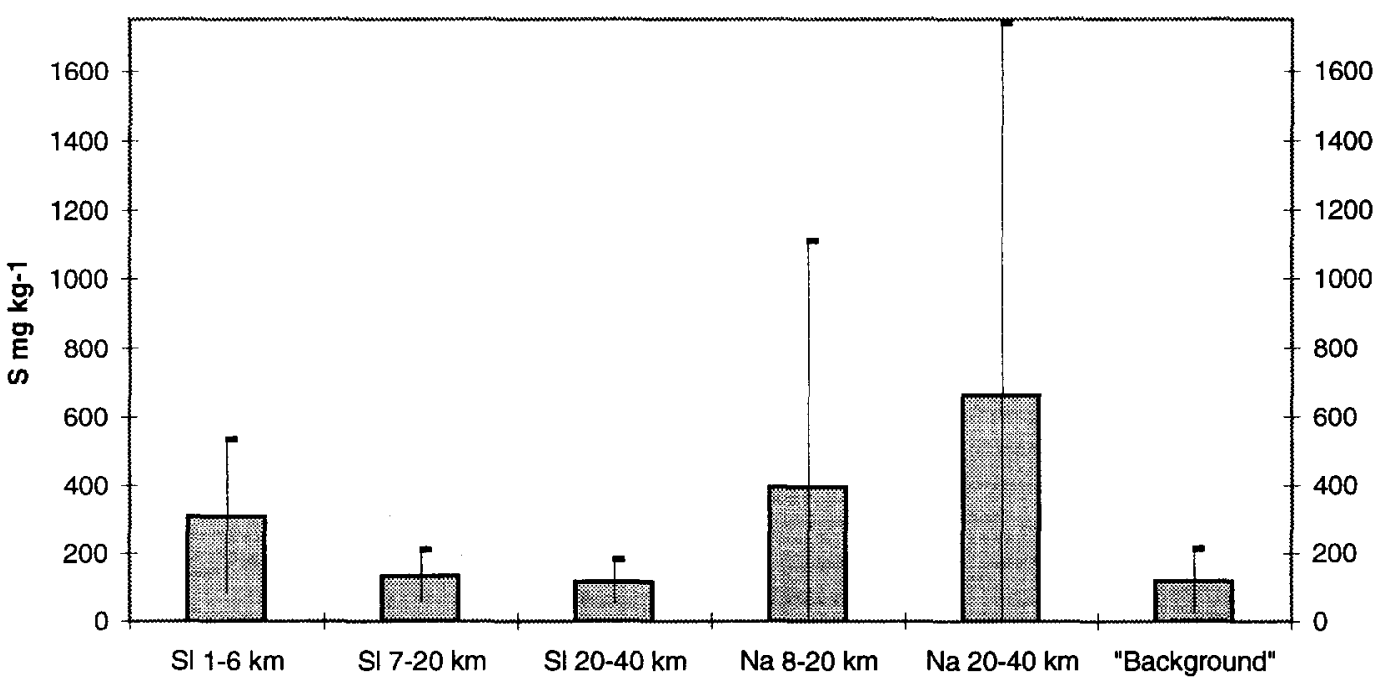

Fig. 10. Exchangeable sulphur content in humus horizon of the Scots pine forests in different parts of the study area. For further explanations, see Figs 2 and 3. 
of the soil not as high as could be expected in the light of such massive pollution. Because $\mathrm{Ca}$ is absorbed much more efficiently, its level in soil rises very high, in the humus layer even to $100000 \mathrm{mg} \mathrm{kg}^{-1}$. Alkalinization dominates the processes of the soil. The transport of $\mathrm{S}$ and $\mathrm{Ca}$ pollutants differs, since $\mathrm{S}$ is mainly transported in its gaseous form as $\mathrm{SO}_{2}$ and $\mathrm{Ca}$ in particle form. For that reason, the greater proportion of the $\mathrm{Ca}$ is deposited at a shorter distance than that of S. This may sharpen the basic-acidic gradient of the study area, which was very obvious.

The effects of such soil pollution on this forest ecosystem is not known. In many parts of the study area, forests are already dead or are suffering from air pollutants. Their injurious effects may have many causes in various ways, including gaseous $\mathrm{SO}_{2}$ interactions. The absence of epiphytic lichens in an area of about $1000 \mathrm{~km}^{2}$ indicates this kind of damage. It is also possible that the alkalinization of pine trunks may contribute to the death of those lichens that are adapted to acidic conditions. This theory is supported by the fact that some epiphytic species did occur on the trunks of pine trees in these polluted areas. These included the lichen Xanthoria parietina and the alga Trentepohlia umbrina, which grow in these ecosystems on Scots pine trunks that are less acidic or on alkaline bark.

The long-term role of soil alkalinization on forests is not yet known. Because pine forest vegetation is adapted to very acid soil, soil alkalinization must negatively impact these areas. An important cause of damage to trees may be via damage to mycorrhizae, which are sensitive to changes in soil acidity.

It could be argued that the forest damage in the study area it not so serious, considering the massive scale of pollution. This may in part be due to the neutralizing effect of acidic and alkaline pollutants. However, if uncontrolled pollution lasts for much longer periods, unanticipated changes should be expected. An indication of this can be found in the great alterations taking place in the soil.

The complicated pollutant situation of the study area must be taken into consideration when environmental protection measures are planned. Major attention has been paid to reducing $\mathrm{SO}_{2}$ emissions from the Narva energy plants. This is important to decrease the injurious effects of gaseous $\mathrm{SO}_{2}$. However, the main problem in the immediate area around the plants comes from alkaline deposition. Therefore, any decrease in the acidic proportion of the deposition may cause even more problems in the soil. It is necessary to reduce both acidic and alkaline emissions at the same time.

\section{ACKNOWLEDGEMENTS}

The authors are very thankful to Pentti Välipakka, the leader of Helsinki University's Kotka Unit, for providing fine working conditions. Thanks are also due to Elena Proletarskaja from the MECHANOBR ANALIT company for the chemical analyses. The authors also thank Anastasia Galkina for participating in the field work and laboratory analyses, Antti Haapala for his help in the ficld, Hannele Pulkkinen for information service and Carol Norris for aiding in translation of this paper.

\section{REFERENCES}

Alva, A. K. \& Sumner, M. E. (1990). Effects of concentration of supporting solution on soil solution aluminum in variable charge soils. Soil Science, 150, 622 -629.

Derome, J. \& Pätilä, A. (1990). Alleviation of forest soil acidification through liming. In Acidification in Finland, ed. P. Kauppi, P. Anttila \& K. Kenttämies. Springer, Berlin, Germany, pp. 1093-1115.

Goltsova, N. (1994). Studies on the Effects of Airborne Pollutants of Estonian Power Plants on Kingisepp and Slantsy Regions. Report on Russian, St Petersburg State University, Russia.

Goltsova, N. \& Vasina, T. V. (1993). Heavy metals retention by the woodland moss Pleurozium shreberi, Leningrad region survey. J. Ecol. Chem., 1, 51-60.

Greszta, J. (1988a) The effects of dusts from electrofilters of different industrial works on forest ecosystems. In Deirimental Effects of Dusts Emitted by Various Industries on Trees and Forest Biotope, ed. J. Greszta. Scientific Papers, 226, Krakóv Agricultural Academy, Poland, pp. 3-21.

Greszta, J. (1988b) Effect of dusts from selected industrial plants on chemical properties of soils. In Detrimental Effects of Dusts Emitted by Various Industries on Trees and Forest Biotope, ed. J. Greszta. Scientific Papers, 226, of Krakóv Agricultural Academy, Poland, pp. 22-64.

Haapala, H., Goltsova, N., Huttunen, S., Seppälä, R., Lamppu, J. \& Kouki, J. (1993). Männyn neulasten rikki-ja kalsiumpitoisuudet Suomenlahden itäosan reuna-alueiden ilmanlaadun indikaattoreina. (Air quality in the forests around the eastern part of the Gulf of Finland as indicated by pine needle $\mathrm{S}$ - and $\mathrm{Ca}$-content). Helsingin yliopiston Kotkan osaston julkaisuja, 3, 51-73.

Haapala, H., Goltsova, N., Seppälä, R., Huttunen, S., Kouki, J., Lamppu, J. \& Popovichev, B. (1996a). Ecological condition of forests around the eastern part of the Gulf of Finland. Environ. Pollut., 91(2), 253-265.

Haapala, H., Goltsova, N. \& Lodenius, M. (1996b) Metalelement content in podzolic soils exposed to the alkalinizing effect of air pollutants. J. Ecol. Chem. (in press).

Huttunen, S., Manninen, S. \& Myllyvirta, T. (1990). Raportti Oy Lohja Ab:n Sipoon tehtaan ympäristövaikutuksista. (The report on the environmental effects of the industrial complex of the Lohja Company in Sipoo). Itä-Uudenmaan ja Porvoonjoen Vesien- ja ilmansuojeluyhdistys r.y. Porvoo, Finland.

Kallaste, T., Roots, O., Saar, J. \& Saare, L. (1992). Air Pollution in Estonia 1985-1990. Environmental Report 3, Environmental Data Centre, National Board of Waters and the Environment. Helsinki, Finland.

Kreutzer, K. (1995). Effects of forest liming on soil processes. Plant Soil, 168-169, 447-470.

Lehto, T. (1984). Kalkituksen vaikutus männyn mykoritsoihin, (English summary: The effect of liming on the mycorrhizae of Scots pine). Folia For., 609, 20 pp.

Lehto, T. (1994). Effects of soil pH and calcium on mycorrhizas of Picea abies. Plant Soil, 163, 69-75.

Menshikova, G. P., Yarmishko, M. A. \& Tichmeneva, I. B. (1993). Changes of litter chemical properties in forest soils under the impact of industrial pollution. In Aerial Pollution in Kola Peninsula, ed. M. V. Kozlov, E. Haukioja \& V. T. Yarmishko). Apatity, Kola Scientific (entre, Russia, pp. 153-155. 
Metzner, E. \& Meuwes, K. J. (1991). Effects of liming and fertilization on soil solution chemistry in North German forest ecosystems. Water Air Soil Pollut., 54, 377-389.

Mäkinen, A. (1994). Laskeuman seuranta bioindikaattoreiden avulla Koillis-Virossa ja Leningradin oblastin länsiosassa v. 1992-1993. (Biomonitoring of Atmospheric Deposition in North-Eastern Estonia and in Western Parts of Leningrad Oblast in 1992-1993). Loppuraportti Uudenmaan lääninhallitukselle, Helsinki, Finland.

Neary, A. J., Mistry, E. \& Vanderstar, L. (1987). Sulphate relationships in some central Ontario forest soils. Canadian J. Soil Sci., 67, 341-352.

Nömmik, H., Larsson, K. \& Ulrik, L. (1984). Effects of Experimental Acidification and Liming on the Transformations of Carbon, Nitrogen and Sulphur in Forest Soils. National Swedish Environment Protection Board Rep. 1869, Solna, Sweden.

Ohtonen, R., Markkola, A. M. \& Torvela, H. (1989). Total sulphur content in humus layer of urban polluted forest soil. Water Air Soil Pollution, 44, 135 141.
Seppälä, R., Goltsova, N. \& Haapala, H. (1993). Suomenlahden itäosan reuna-alueiden mäntymetsien bioindikaattoritutkimukset, (Report on the Bioindicator Studies in the Forests around the Eastern Part of the Gulf of Finland). Helsingin yliopiston Kotkan osaston julkaisuja, 3, 75-119.

Synthesis report (1991). Environmental Priority Action Programme for Leningrad, Leningrad Region, Karelia and Estonia. Ministry of the Environment of Finland, Helsinki, Finland.

Tamminen, P. \& Starr, M. R., (1990). A survey of forest soil properties related to soil acidification in southern Finland. In Acidification in Finland, ed. P. Kauppi, P. Anttila \& K. Kenttämies, Springer, Berlin, Germany, pp. 235-251.

Thomas, G. W. \& Hargrove, W. L. (1984). The chemistry of soil acidity. In Soil Acidity and Liming, ed. F. Adams. Agronomy Series, American Society of Agronomy, Madison, WI, 12, pp. 3-56.

VTT, (1994). Emissions from Estonian and Baltic oil-shale power plant. Final report, VVT, Helsinki, Finland. 